International Research Journal of Management, IT \& Social Sciences
Available online at https://sloap.org/journals/index.php/irjmis/
Vol. 7 No. 1, January 2020, pages: 185-196
ISSN: 2395-7492
https://doi.org/10.21744/irjmis.v7n1.836

\title{
Effect of Mobile Service Quality to E-Trust to Develop E- Satisfaction and E-Loyalty Mobile Banking Services
}

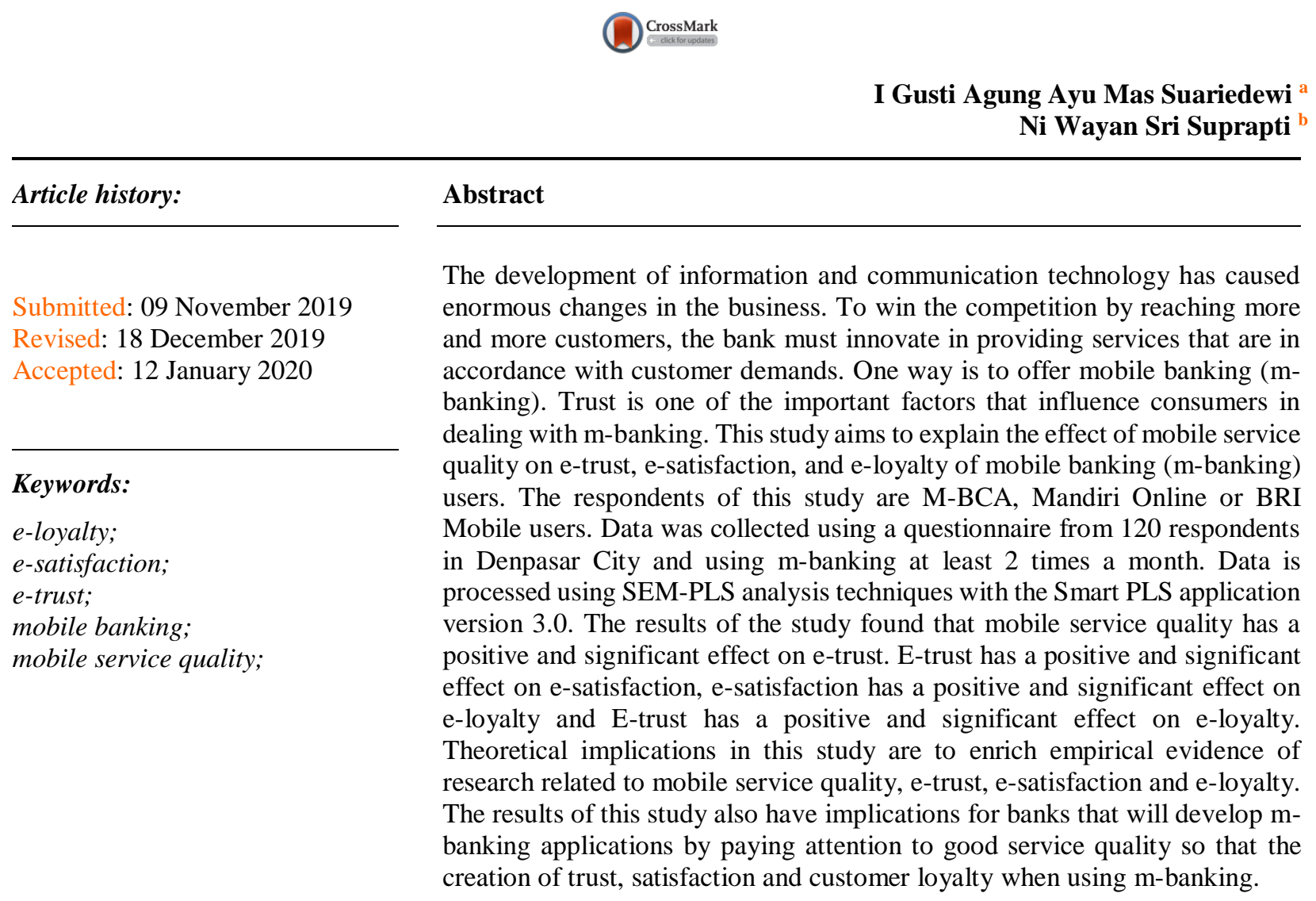

International research journal of management, IT and social sciences (C) 2020. This is an open access article under the CC BY-NC-ND license (https://creativecommons.org/licenses/by-nc-nd/4.0/).

\section{Corresponding author:}

I Gusti Agung Ayu Mas Suariedewi,

Fakultas Ekonomi dan Bisnis, Universitas Udayana, Denpasar, Indonesia.

Email address: agungsuariedewi@gmail.com

\footnotetext{
Udayana University, Denpasar, Indonesia

${ }^{\mathrm{b}}$ Udayana University, Denpasar, Indonesia
} 


\section{Introduction}

The development of information and communication technology has caused enormous changes in the business. The existence of the internet has caused the way of doing business must always be adapted to the conditions of consumers who demand that services can be provided quickly, easily, and cheaply, not least in banking services. To win the competition by reaching more and more customers with better financial potential, banks inevitably have to innovate in providing services that are in line with customer demands. One way is to offer mobile banking (m-banking), which is an information technology-based banking service. This m-banking service is very potential considering that internet users in Indonesia are very large. Data from the 2018 APJII survey show that internet users in Indonesia number 171.17 million people. In other words, this number represents $64.5 \%$ percent of the entire population in Indonesia.

Based on the results of a survey conducted by APJII in 2018, the percentage of internet penetration in Bali was $59 \%$ and $41 \%$ were not yet active using the internet. This shows that most of the people in Bali use the internet for daily activities. The results of this survey show that the majority of people in Indonesia have not yet utilized optimally the use of banking transactions. One of the things related to using m-banking is the customer's trust to use the service, which is known as e-trust terminology. Banks that have branch offices in Denpasar City that have offered m-banking applications include Bank Mandiri, BCA Bank, and BRI Bank, where the three banks are the banks with the highest number of m-banking customers. Not yet optimal internet users to use m-banking are indicated by the results of a preliminary survey of 60 bank customers in the city of Denpasar. All respondents were familiar with using the internet, but only $56.7 \%$ of respondents had used m-banking. The number of M-BCA users with a percentage of $11.7 \%$, Mandiri Online 28.3\%, BRI Mobile 11.7\% and Bukopin Mobile 5\%, then $43.3 \%$ of respondents claimed not to use m-banking. This study aims to determine the effect of mobile service quality on e-trust, e-satisfaction and e-loyalty of mobile banking (m-banking) M-BCA, Mandiri Online and BRI Mobile users.

\section{Literature review}

Mobile service quality

E-Service Quality or E-SQ refers to services offered through the internet. According to Al-dweeri et al. (2017), MSQ is part of e-commerce and has been explored as a multi-dimensional concept adapted from e-SQ. Mobile service quality (MSQ) is the quality of cellular services as a consumer assessment of the quality and superiority of cellular content delivery in the context of m-banking. Bharti (2016), states supportive access to m-banking is related to user satisfaction. Kumar et al. (2017), states that there are several dimensions of mobile service quality (MSQ), namely, design, functional, guarantee, and customization. Meanwhile, according to Zoghlami et al. (2018), dimensions of mobile service quality (MSQ) consist of information quality, privacy, reliability, design, and ease of use.

\section{E-Trust}

E-Trust is defined as the formation of attitudes between customers and sellers including consumer beliefs and expectations regarding characteristics related to trust from online sellers. Various activities related to trust play an important role, so trust can be said to be a key factor in the success of e-commerce (Daniyan-Bagudu et al., 2017; Gong et al., 2018). Consumers when shopping online tend to want that the seller is willing and able to meet the interests of consumers, maintain honesty in the transaction, and must be able to provide goods and services as promised. Luarn \& Juo (2010), in their research, stated that trust in technology influences perceived ease of use in determining user behavior intentions. Gefen et al. (2008), state that e-trust indicators consist of competence, integrity and virtue. While the indicators of consumer confidence variables refer to Robbins (2001), consisting of integrity, competence, consistency, loyalty, and openness.

\section{E-Satisfaction}

Hansemark \& Albinsson (2004), states satisfaction is the overall attitude of customers towards service providers or emotional reactions to differences between what they expect and what they receive about their needs, goals and desires. E-Satisfaction is one of the developments of customer satisfaction in the field of e-commerce, where transactions are carried out through internet network facilities (Komara, 2015). Consumer satisfaction is defined as customer satisfaction or dissatisfaction after conducting transactions through internet media (Mulyawan \& Sidharta, 2014). ESatisfaction is seen as an overall construct that reflects the cumulative effect of a series of different experiences with 
service providers over a period of time. The indicator to measure this variable refers to Ding et al. (2016), states that the indicator on e-satisfaction consists of being satisfied with the m-banking application on a smartphone, a pleasant experience using the m-banking application, and the performance of the m-banking application according to is expected.

\section{E-Loyalty}

The company needs loyal customers because customers are the company's assets. In order to create customer loyalty, the company must provide the best quality of service from the products offered. According to Melaning \& Giantari (2019), user loyalty comes from how much the company's performance to generate satisfaction by minimizing complaints. A focus on customer loyalty is important in mobile banking to maintain a committed relationship with customers. Yaqin \& Ilfitriah (2015), states that consumer loyalty is not formed in a short time but through a learning process that is based on the experiences of consumers themselves based on repurchases. So, in this case, it can be said that consumer loyalty has arisen.

E-customer loyalty (electronic customer loyalty) is a new concept and is considered a branch of the concept of loyalty, which is implemented in the e-commerce context. Chen et al. (2014), stated that there are several indicators of consumer e-loyalty, namely recommending the m-banking site to others, encouraging friends and others to transact through the m-banking application and saying positive things about m-banking to others. Customer loyalty is a customer commitment to a brand, store, supplier, based on a positive attitude that is reflected in a consistent repurchase (Tjiptono, 2006). Customer loyalty is very important in relation to business development, customers who are loyal will always use the products/services provided by the company. Kotler \& Keller (2004), state loyalty can be measured by 3 indicators, namely repeat purchase, retention and referral.

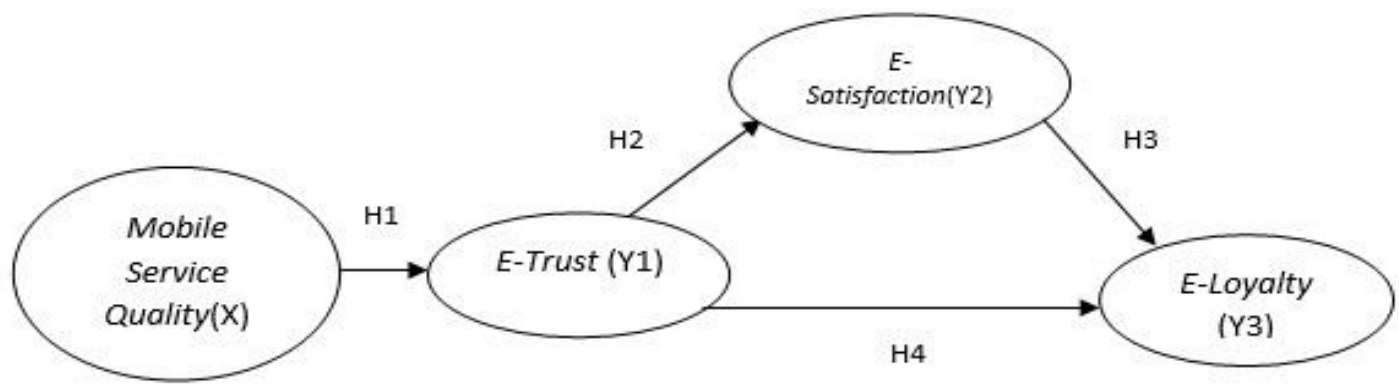

Figure 1. Conceptual framework

\section{Effect of mobile service quality on E-trust}

The effect of e-service quality on e-trust has been well explored by previous studies. Previous research has shown how information quality can increase trust. The more customers appreciate the quality of services offered, the more they have a higher level of trust in the company. Reliability is also significant in determining user trust in websites (Permana \& Djatmiko, 2018). On the other hand, security is fundamental in electronic commerce. A secure account with an ID and password can be convincing social media users (Alam et al., 2017). Another study shows how web site design can build e-trust. In the context of mobile applications, ease of use can increase customer confidence (Richard, 2013). Based on the results of these studies, the following hypothesis can be formulated:

H1: Mobile service quality has a positive and significant effect on e-trust.

\section{Effect of E-trust on E-satisfaction}

The overall assessment of what is felt by consumers in previous experiences (including the results of service fulfillment, expectations, and needs) is an antecedent of consumer behavior and trust. Masrek et al. (2012), states the relationship between consumers and banks through m-banking applications, where when consumers feel the technology is trusted, they will evaluate m-banking as a profitable way and become satisfied. The study conducted by Jimenez et al. (2016), stated that the higher level of customer satisfaction in e-commerce will increase trust in sellers

Suariedewi, I. G. A. A. M., \& Suprapti, N. W. S. (2020). Effect of mobile service quality to e-trust to develop esatisfaction and e-loyalty mobile banking services. International Research Journal of Management, IT and Social Sciences, 7(1), 185-196. https://doi.org/10.21744/irjmis.v7n1.836 
who use the application. Trust must be formed first to satisfy consumers. Based on the results of these studies, the following hypothesis can be formulated:

H2: E-Trust has a positive and significant effect on E-satisfaction.

Effect of E-satisfaction on E-loyalty

In the financial sector, trust is the basis for maintaining long-lasting relationships with customers (Berraies et al. 2015). Loyal customers are those who already trust the company. Building trustworthy relationships with clients are important in risky contexts such as online transactions mainly because of the uncertain online environment. Satisfaction felt by consumers can increase the intensity of the use of m-banking and encourage loyalty to satisfied consumers (Basri, 2019). Based on the results of these studies, the following hypotheses can be formulated:

H3: E-Satisfaction has a positive and significant effect on E-loyalty.

Effect of E-trust on E-loyalty

Research conducted by Revita (2016), states that e-trust influences e-loyalty, where the more trust consumers have in online businesses, the more loyal consumers will not switch. A study conducted by Husain (2017), states the trust factor is considered as the most important factor for customers in deciding to make their purchases in an online context so that it will have an impact on loyalty. Based on the results of these studies, the following hypothesis can be formulated:

H4: E-Trust has a positive and significant effect on E-loyalty for mobile banking users.

\section{Materials and Methods}

This research was conducted in the city of Denpasar, where the population in this study were all residents who live in the city of Denpasar using M-BCA, Mandiri Online or BRI Mobile applications. These three banks were chosen because based on the Top Brand Award survey, M-BCA, Mandiri Online, and BRI Mobile occupy the top three best $\mathrm{m}$-banking positions chosen by respondents. Determination of the sample using a purposive sampling technique, wherein determining the sample based on predetermined criteria. The criteria for respondents are domiciled in the city of Denpasar, at least high school education level, and actively using one of the m-banking applications, between Mandiri Online, M- BCA, or BRI Mobile and transacting in one month at least 2 times. Data is processed using the Smart PLS program.

\section{Results and Discussions}

Table 1

Characteristics of the respondent

\begin{tabular}{lllll}
\hline No & Variable & Classification & Total & $\begin{array}{l}\text { Percentage } \\
(\%)\end{array}$ \\
\hline 1 & Gender & Man & 58 & 48,3 \\
& & Woman & 62 & 51,6 \\
2 & Total & 120 & 100 \\
& M-Banking & BCA Mobile & 47 & 39,1 \\
& & Mandiri Online & 36 & 30 \\
& & 37 & 30,8 \\
3 & Las Mobile & 120 & 100 \\
& Last education & Total & 19 & 15,8 \\
& & High school & 86 & 71,6 \\
& & Bachelor & 15 & 12,5 \\
& & Postgraduate & 100 \\
& & Postgraduate (Doctor) & 0 & \\
& & Total & 120 & 100 \\
\hline
\end{tabular}




\begin{tabular}{|c|c|c|c|c|}
\hline \multirow[t]{6}{*}{4} & Job & Student & 26 & 21,6 \\
\hline & & PNS & 14 & 11,6 \\
\hline & & Private Employees & 57 & 47,5 \\
\hline & & Entrepreneur & 18 & 15 \\
\hline & & Others & 5 & 4,3 \\
\hline & & Total & 120 & 100 \\
\hline \multirow[t]{5}{*}{5} & Usage Frequency & 2 times & 28 & 23,3 \\
\hline & & $>2-4$ times & 37 & 30,8 \\
\hline & & $>4-6$ times & 24 & 20 \\
\hline & & $>6$ times & 31 & 25,8 \\
\hline & & Total & 120 & 100 \\
\hline
\end{tabular}

Based on Table 1 it can be seen that the number of male respondents who participated in this study was $48.3 \%$ while female respondents were $51.6 \%$. The majority of respondents in this study were female. The number of respondents using M-BCA occupied the largest percentage at 39.1\%, followed by Mandiri Online users at 30\% and BRI Mobile at $30.8 \%$. S1 education level occupies the largest percentage at $71.6 \%$, followed by high school education level $15.8 \%$ and $\mathrm{S} 2$ at $12.5 \%$.

The majority of respondents work as private employees as indicated by a percentage of $47.5 \%$, the profession of students is $21.6 \%$ and PNS is $11.6 \%$. Then, based on the frequency of use of the majority of respondents using the mbanking application> 2-4 times with a percentage of $30.8 \%$ for 1 month. Respondents who transacted> 6 times were $25.8 \%$ and transactions were twice that of $23.3 \%$. This states that the average respondent has been actively using $\mathrm{m}-$ banking for transaction activities in one month. The results of the research instrument test in the form of validity and reliability are presented in Table 2 and Table 3.

Table 2

Validity test

\begin{tabular}{llll}
\hline Variables & Indicators & $\begin{array}{l}\text { Pearson } \\
\text { Correlation }\end{array}$ & Validity \\
\hline Mobile Service Quality $(X)$ & $(\mathrm{X} 1.1)$ & 0,928 & Valid \\
& $(\mathrm{X} 1.2)$ & 0,937 & Valid \\
& $(\mathrm{X} 2.1)$ & 0,913 & Valid \\
& $(\mathrm{X} 2.2)$ & 0,931 & Valid \\
& $(\mathrm{X} 2.3)$ & 0,940 & Valid \\
& $(\mathrm{X} 3.1)$ & 0,929 & Valid \\
& $(\mathrm{X} 3.2)$ & 0,937 & Valid \\
& $(\mathrm{X} 4.1)$ & 0,928 & Valid \\
E-Trust (Y1) & $(\mathrm{X} 4.2)$ & 0,947 & Valid \\
& $(\mathrm{Y} 1.1)$ & 0,856 & Valid \\
& $(\mathrm{Y} 1.2)$ & 0,884 & Valid \\
E-Satisfaction $(\mathrm{Y} 2)$ & $(\mathrm{Y} 1.3)$ & 0,908 & Valid \\
& $(\mathrm{Y} 2.1)$ & 0,916 & Valid \\
E-Loyalty (Y3) & $(\mathrm{Y} 2.2)$ & 0,943 & Valid \\
& $(\mathrm{Y} 3.1)$ & 0,915 & Valid \\
& $(\mathrm{Y} 3.2)$ & 0,905 & Valid \\
& $(\mathrm{Y} 3.3)$ & 0,943 & Valid \\
\hline
\end{tabular}

The validity test gives the correlation value between 0.856 to 0.947 , which has a correlation coefficient above 0.3 . Based on these test results it can be concluded that the research instrument was declared valid

Suariedewi, I. G. A. A. M., \& Suprapti, N. W. S. (2020). Effect of mobile service quality to e-trust to develop esatisfaction and e-loyalty mobile banking services. International Research Journal of Management, IT and Social Sciences, 7(1), 185-196. https://doi.org/10.21744/irjmis.v7n1.836 
Table 3

Reliability test

\begin{tabular}{llll}
\hline Variable & Indicator & Cronbach Alpha & Reliability \\
\hline Mobile Service Quality (X) & $(\mathrm{X} 1.1)$ & 0,741 & Reliable \\
& $(\mathrm{X} 1.2)$ & 0,741 & Reliable \\
& $(\mathrm{X} 2.1)$ & 0,841 & Reliable \\
& $(\mathrm{X} 2.2)$ & 0,820 & Reliable \\
& $(\mathrm{X} 2.3)$ & 0,849 & Reliable \\
& $(\mathrm{X} 3.1)$ & 0,741 & Reliable \\
& $(\mathrm{X} 3.2)$ & 0,741 & Reliable \\
& $(\mathrm{X} 4.1)$ & 0,758 & Reliable \\
& $(\mathrm{X} 4.2)$ & 0,758 & Reliable \\
& $(\mathrm{Y} 1.1)$ & 0,706 & Reliable \\
& $(\mathrm{Y} 1.2)$ & 0,732 & Reliable \\
& $(\mathrm{Y} 1.3)$ & 0,767 & Reliable \\
E-Srust (Y1) & $(\mathrm{Y} 2.1)$ & 0,730 & Reliable \\
& $(\mathrm{Y} 2.2)$ & 0,730 & Reliable \\
E-Loyalty $(\mathrm{Y} 3)$ & $(\mathrm{Y} 3.1)$ & 0,809 & Reliable \\
& $(\mathrm{Y} 3.2)$ & 0,775 & Reliable \\
& $(\mathrm{Y} 3.3)$ & 0,871 & Reliable
\end{tabular}

The reliability test gives the result that, the entire Cronbach alpha value of the research variable is between 0.706 to 0.849, where the Cronbach variable value is above 0.6. Based on these test results it can be concluded that the research instrument is declared reliable.

Table 4

Output convergent validity

\begin{tabular}{ll}
\hline Indicator & Factor Loading \\
\hline (X1.1) & 0,908 \\
$(\mathrm{X} 1.1)$ & 0,909 \\
$(\mathrm{X} 1.2)$ & 0,878 \\
$(\mathrm{X} 2.1)$ & 0,846 \\
$(\mathrm{X} 2.2)$ & 0,887 \\
$(\mathrm{X} 2.3)$ & 0,912 \\
$(\mathrm{X} 3.1)$ & 0,916 \\
$(\mathrm{X} 3.2)$ & 0,927 \\
(X4.1) & 0,931 \\
$(\mathrm{X} 4.2)$ & 0.914 \\
$(\mathrm{Y} 1.1)$ & 0.908 \\
(Y1.2) & 0.854 \\
(Y1.3) & 0.918 \\
(Y2.1) & 0.913 \\
(Y2.2) & 0.875 \\
(Y3.1) & 0.887 \\
(Y3.2) & 0.909 \\
\hline
\end{tabular}

Table 4. shows all indicators of Mobile Service Quality, E-Trust, E-Satisfaction and E-Loyalty that have outer loadings values greater than 0.70 . This indicator is a valid indicator for measuring variables 
Table 5

Output AVE

\begin{tabular}{ll}
\hline Variable & $\begin{array}{l}\text { Average Variance Extracted } \\
\text { (AVE) }\end{array}$ \\
\hline Mobile Service Quality (X1) & 0,688 \\
Information Quality (X1.1) & 0,825 \\
Reliability (X1.2) & 0,758 \\
Design (X1.3) & 0,836 \\
Ease of Use (X1.4) & 0,863 \\
E-Trust (Y1) & 0,796 \\
E-Satisfaction (Y2) & 0,838 \\
E-Loyalty (Y3) & 0,793 \\
\hline
\end{tabular}

Based on the output in Table 5. it can be seen that all variables have Table 4. AVE values are more than 0.5 , so the variable is declared to have good validity

Table 6

Cross loading value

\begin{tabular}{|c|c|c|c|c|c|c|c|}
\hline Indicators & $\begin{array}{l}\text { Information } \\
\text { Quality } \\
\text { (X1.1) }\end{array}$ & $\begin{array}{l}\text { Reliability } \\
\text { (X2.1) }\end{array}$ & $\begin{array}{l}\text { Design } \\
(\mathrm{X} 3.1)\end{array}$ & $\begin{array}{l}\text { Ease of Use } \\
(\mathrm{X} 4.1)\end{array}$ & $\begin{array}{l}\text { E-Trust } \\
(Y 1)\end{array}$ & $\begin{array}{l}\text { E-Satisfaction } \\
\text { (Y2) }\end{array}$ & $\begin{array}{l}\text { E-Loyalty } \\
(Y 3)\end{array}$ \\
\hline (X1.1) & 0.908 & 0.768 & 0.720 & 0.672 & 0.789 & 0.651 & 0.604 \\
\hline (X1.2) & 0.909 & 0.718 & 0.771 & 0.714 & 0.728 & 0.596 & 0.592 \\
\hline (X2.1) & 0.744 & 0.878 & 0.658 & 0.651 & 0.699 & 0.548 & 0.566 \\
\hline (X2.2) & 0.640 & 0.846 & 0.683 & 0.686 & 0.703 & 0.565 & 0.608 \\
\hline (X2.3) & 0.750 & 0.887 & 0.756 & 0.709 & 0.721 & 0.551 & 0.633 \\
\hline (X3.1) & 0.720 & 0.732 & 0.912 & 0.695 & 0.728 & 0.544 & 0.558 \\
\hline (X3.2) & 0.780 & 0.738 & 0.916 & 0.697 & 0.746 & 0.553 & 0.574 \\
\hline (X4.1) & 0.683 & 0.703 & 0.719 & 0.927 & 0.742 & 0.621 & 0.781 \\
\hline (X4.2) & 0.734 & 0.752 & 0.696 & 0.931 & 0.758 & 0.652 & 0.743 \\
\hline (Y1.1) & 0.757 & 0.709 & 0.738 & 0.723 & 0.914 & 0.613 & 0.608 \\
\hline (Y1.2) & 0.776 & 0.757 & 0.713 & 0.742 & 0.908 & 0.647 & 0.655 \\
\hline (Y1.3) & 0.700 & 0.708 & 0.708 & 0.696 & 0.854 & 0.643 & 0.588 \\
\hline (Y2.1) & 0.690 & 0.604 & 0.570 & 0.645 & 0.671 & 0.918 & 0.727 \\
\hline (Y2.2) & 0.565 & 0.561 & 0.528 & 0.610 & 0.630 & 0.913 & 0.723 \\
\hline (Y3.1) & 0.519 & 0.581 & 0.504 & 0.675 & 0.549 & 0.700 & 0.875 \\
\hline (Y3.2) & 0.645 & 0.647 & 0.599 & 0.747 & 0.642 & 0.717 & 0.887 \\
\hline (Y3.3) & 0.590 & 0.619 & 0.548 & 0.765 & 0.655 & 0.699 & 0.909 \\
\hline
\end{tabular}

Based on Table 6 the value of cross loading dimensions of mobile service quality $(\mathrm{X})$ has the greatest value compared with the correlation with indicators of e-trust (Y1), e-satisfaction (Y2) and e-loyalty (Y3). The value of cross-loading e-trust (Y1) has the greatest value compared with the correlation with indicators of e-satisfaction (Y2), e-loyalty (Y3) and the dimensions of mobile service quality (X). Similarly, the value of cross-loading e-satisfaction (Y2) and e-loyalty (Y3) which has the greatest value compared to other indicators

Table 7

Composite reliability and Cronbach Alpha

\begin{tabular}{lll}
\hline Variable & Cronbach's Alpha & Composite Reliability \\
\hline Mobile Service Quality (X1) & 0,943 & 0,952 \\
Information Quality (X1.1) & 0,788 & 0,904 \\
\hline
\end{tabular}

Suariedewi, I. G. A. A. M., \& Suprapti, N. W. S. (2020). Effect of mobile service quality to e-trust to develop esatisfaction and e-loyalty mobile banking services. International Research Journal of Management, IT and Social Sciences, 7(1), 185-196. https://doi.org/10.21744/irjmis.v7n1.836 


\begin{tabular}{lll}
\hline Reliability (X1.2) & 0,840 & 0,904 \\
Design (X1.3) & 0,804 & 0,911 \\
Ease of Use (X1.4) & 0,841 & 0,926 \\
E-Trust (Y1) & 0,871 & 0,921 \\
E-Satisfaction (Y2) & 0,806 & 0,912 \\
E-Loyalty (Y3) & 0,869 & 0,920 \\
\hline
\end{tabular}

Based on the output results in Table 7. shows that the composite reliability and Cronbach alpha show the value of each variable above the minimum value of 0.60 . This shows that all the constructs or variables of this study have become a fit measurement tool, and all statements used to measure each construct have good reliability. Inner Model Evaluation aims to determine the goodness of fit model with the R-Square (R2) method.

Table 8

R-Square value

\begin{tabular}{ll}
\hline Variable & Score \\
\hline Mobile Service Quality (X1) & 0,849 \\
Information Quality (X1.1) & 0,882 \\
Reliability (X1.2) & 0,839 \\
Design (X1.3) & 0,802 \\
E-Trust (Y1) & 0,786 \\
E-Satisfaction (Y2) & 0,506 \\
E-Loyalty (Y3) & 0,661 \\
\hline
\end{tabular}

Based on Table 8 it can be seen if the R-Square value of the e-loyalty variable is 0.661 . This is interpreted that $66.1 \%$ of the variability of the e-loyalty variable is explained by the variable mobile service quality, e-trust, and e-satisfaction. While $33.1 \%$ of e-loyalty variables are explained by variables outside the model. Then, $50.6 \%$ of e-satisfaction variability is explained by mobile service quality and e-trust variables. While $49.4 \%$ of e-satisfaction variables are explained by variables outside the model. The e-trust variability of $78.6 \%$ is explained by the mobile service quality variable. Whereas $50.6 \%$ of e-trust variables are explained by variables outside the model. Q-Square (Predictive Relevance) measures how well the observed value generated by the estimation model and its parameters. Q-Square value $>0$ indicates the model has good predictive relevance. The Q-Square (Predictive Relevance) value can be calculated as follows:

$$
\begin{aligned}
& \mathrm{Q}^{2}=1-\left(1-\mathrm{R}^{2} 1\right)\left(1-\mathrm{R}^{2}\right)\left(1-\mathrm{R}_{3}{ }_{3}\right)\left(1-\mathrm{R}_{4}^{2}\right)\left(1-\mathrm{R}_{5}^{2}\right)\left(1-\mathrm{R}_{6}^{2}\right)\left(1-\mathrm{R}_{7}{ }_{7}\right) \\
& \mathrm{Q}^{2}=1-(1-0,849)(1-0,882)(1-0,839)(1-0,802)(1-0,786)(1-0,506)(1-0,661) \\
& \mathrm{Q}^{2}=1-(0,00002036) \\
& \mathrm{Q}^{2}=0,999
\end{aligned}
$$

Calculation of Q-square (Predictive Relevance) in this model is worth 0.999 or more than 0, the model can be said to be a good predictive relevance and a value of 0.999 means the relationship between variables can be explained $99 \%$ by the model

Table 9

Output path coefficient test

\begin{tabular}{llll}
\hline Relationship between variables & Path Coefficient & T Statistic & P Values \\
\hline Mobile Servqual -> E-trust & 0.886 & 54.626 & 0.000 \\
E-trust -> E-Satisfaction & 0.711 & 15.771 & 0.000 \\
E-Satisfaction -> E-Loyalty & 0.607 & 6.344 & 0.000 \\
E-trust -> E-Loyalty & 0.260 & 2.527 & 0.012 \\
\hline
\end{tabular}


Hypothesis testing can be done using t-statistics or by looking at the p-value with Alpha used at 0.05 . If the t-statistic value $\geq \mathrm{t}$-table value $(1.99346)$ or $\mathrm{p}$-value $<0.05$, the research hypothesis is accepted. In Table 9 it can be seen that the mobile service quality of e-trust has a correlation coefficient of 0.886 ; with the t-statistics value of 54,626 (54,626 $\geq 1,99346)$ and a $p$-value of $0,000(0,000<0,05)$, the research hypothesis was accepted. This shows that there is a positive influence between mobile service quality variables on e-trust. The better the mobile service quality service will affect consumer confidence in using the m-banking application.

The influence of e-trust on e-satisfaction has a correlation coefficient of 0.711 ; with t-statistics value of 15,771 $(15,771 \geq 1,99346)$ and with a p-value of $0,000(0,000<0,05)$, the research hypothesis was accepted. This shows that there is a positive influence of e-trust on e-satisfaction. The higher consumer confidence in m-banking, it will affect consumer satisfaction in using m-banking application Furthermore the e-satisfaction variable on e-loyalty has a correlation coefficient of 0.607; with the t-statistics value of $6.344(6.344 \geq 1.99346)$ and with a p-value of $0.000(0.000$ $<0.05)$, the research hypothesis is accepted. This shows that there is a positive effect of e-satisfaction on consumer eloyalty. The higher customer satisfaction in using m-banking applications will have an impact on consumer loyalty to continue using m-banking.

The e-trust variable for e-loyalty has a correlation coefficient of 0.260 ; with the t-statistics value of 2.527 (2.527 $\geq 1.99346)$ and with a p-value of $0.012(0.012<0.05)$, the research hypothesis was accepted. This shows that there is a positive influence of e-trust on consumer e-loyalty. The higher consumer confidence in using m-banking applications will have an impact on consumer loyalty to continue using m-banking.

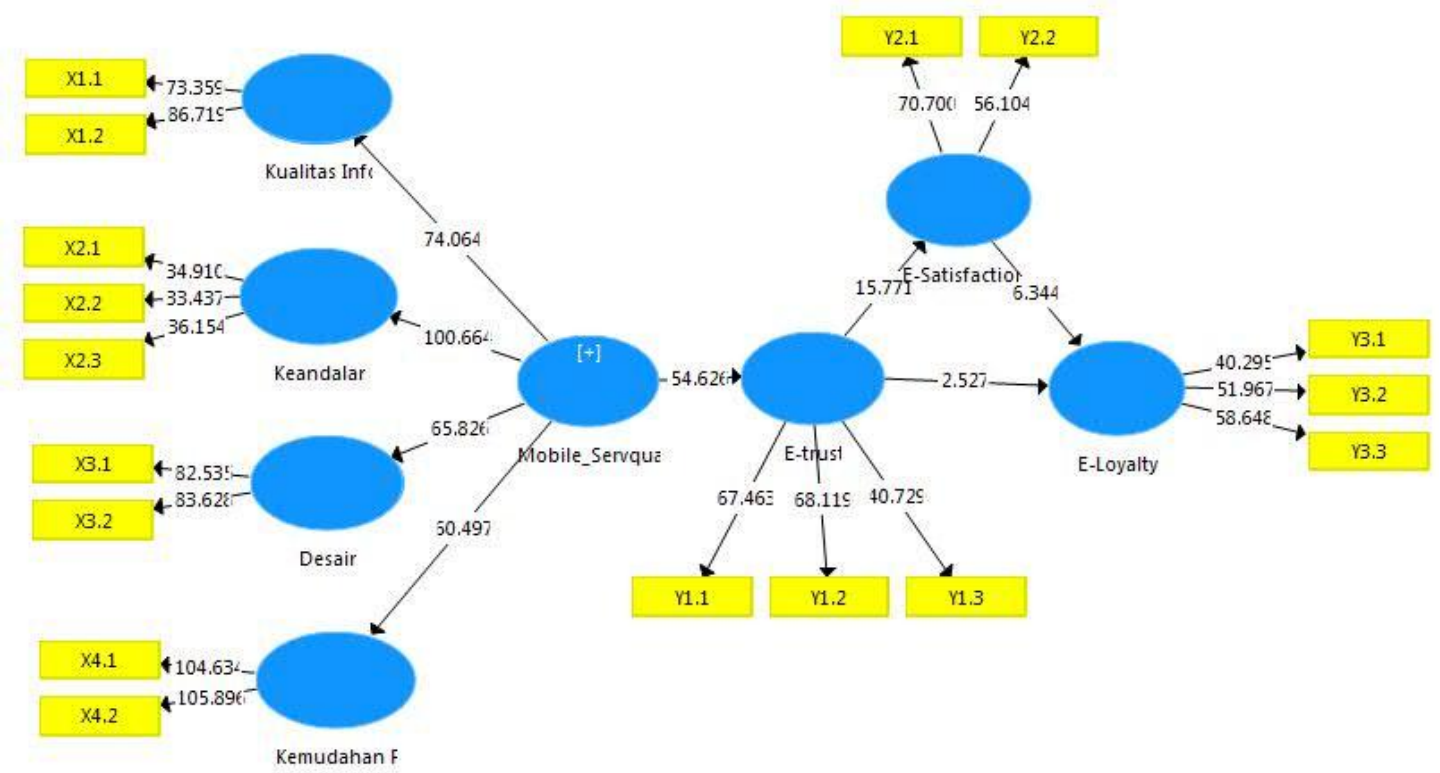

Figure 2. Impact on consumer loyalty to continue using m-banking

\section{Conclusion}

Based on the results of the research discussion with the path analysis that has been done, it can be concluded that mobile service quality (MSQ) has a positive and significant effect on the e-trust of customers using m-banking applications. This shows that the higher the quality of services provided, the more confidence the customer has in $\mathrm{m}-$ banking application. E-trust has a positive and significant effect on the e-satisfaction of customers using m-banking applications. This proves that the higher the customer's trust in m-banking application, the more satisfaction they will have with m-banking service. E-Satisfaction has a positive and significant effect on e-loyalty of customers using mbanking applications. This proves that the more satisfied the customer is with $\mathrm{m}$-banking services offered, it will affect the loyalty to continue using m-banking application. E-Trust has a positive and significant effect on e-loyalty of customers using m-banking applications. This proves the customer's trust in $\mathrm{m}$-banking services offered will affect the loyalty to continue using the m-banking application.

Suariedewi, I. G. A. A. M., \& Suprapti, N. W. S. (2020). Effect of mobile service quality to e-trust to develop esatisfaction and e-loyalty mobile banking services. International Research Journal of Management, IT and Social Sciences, 7(1), 185-196. https://doi.org/10.21744/irjmis.v7n1.836 
In the mobile service quality variable respondents' ratings of mobile service quality generally show a high score. However, the dimension of information quality occupies the lowest average value of 3.70. Suggestions that can be shown to banks that will develop m-banking applications should make applications with menu choices that are easy to understand, up-to-date m-banking information. In the e-trust variable, the results of respondents' responses to the trust indicator provide personal information that has the lowest value of 3.57. Suggestions can be given, the bank needs to improve the security of the m-banking system, for example, periodic password changes. In the e-satisfaction variable, the results of respondents' responses to the m-banking service indicators are expected to have the lowest value of 3.76 . Suggestions can be given by banks to improve service quality so that customers will be satisfied with the bank's services. In the e-loyalty variable, the results of the respondents' responses to the indicator chose to use m-banking compared to other applications occupying the lowest value of 3.82. Suggestions that can be given, the bank should maintain a loyal attitude of customers by improving the quality of m-banking services, giving reward prizes to customers and so forth.

\section{Conflict of interest statement}

The authors declared that they have no competing interests.

\section{Statement of authorship}

The authors have a responsibility for the conception and design of the study. The authors have approved the final article.

\section{Acknowledgments}

The authors would like to thank the editor of IRJMIS for their valuable time, support and advice in completing the current study. 


\section{References}

Alam, S. S., Ahmad, M., Khatibi, A. A., \& Ahsan, M. N. (2017). Factors affecting trust in publishing personal information in online social network: An empirical study of Malaysia's Klang Valley users. Geografia: Malaysian Journal of Society and Space, 12(2).

Al-dweeri, R. M., Obeidat, Z. M., Al-dwiry, M. A., Alshurideh, M. T., \& Alhorani, A. M. (2017). The impact of eservice quality and e-loyalty on online shopping: moderating effect of e-satisfaction and e-trust. International Journal of Marketing Studies, 9(2), 92. http://doi.org/10.5539/ijms.v9n2p92

Basri, A. I. (2019). Pengaruh Kualitas Layanan Terhadap Kepuasan dan Loyalitas Nasabah Bank Pengguna EBanking. Bisman (Bisnis \& Manajemen): The Journal of Business and Management, 2(1), 1-18.

Berraies, S., Chtioui, R., \& Yahia, K. B. (2015). Functional characteristics of banking websites and customer loyalty: the mediating role of online trust. Journal of Applied Business Research (JABR), 31(3), 911-924. https://doi.org/10.19030/jabr.v31i3.9246

Bharti, S. K., Vachha, B., Pradhan, R. K., Babu, K. S., \& Jena, S. K. (2016). Sarcastic sentiment detection in tweets streamed in real time: a big data approach. Digital Communications and Networks, 2(3), 108-121. https://doi.org/10.1016/j.dcan.2016.06.002

Chen, C., Dubin, R., \& Kim, M. C. (2014). Emerging trends and new developments in regenerative medicine: A scientometric update (2000-2014). Expert Opinion on Biological Therapy, 14(9), 1295-1317. https://doi.org/10.1517/14712598.2014.920813

Chinomona, R. (2013). The influence of perceived ease of use and perceived usefulness on trust and intention to use mobile social software: technology and innovation. African Journal for Physical Health Education, Recreation and Dance, 19(2), 258-273.

Daniyan-Bagudu, H., Khan, S. J. M., \& Roslan, A.-H. (2017). The effect of mobile banking on the performance of commercial banks in Nigeria. International Research Journal of Management, IT and Social Sciences, 4(2), 74-80.

Ding, D., Lawson, K. D., Kolbe-Alexander, T. L., Finkelstein, E. A., Katzmarzyk, P. T., Van Mechelen, W., ... \& Lancet Physical Activity Series 2 Executive Committee. (2016). The economic burden of physical inactivity: a global analysis of major non-communicable diseases. The Lancet, 388(10051), 1311-1324. https://doi.org/10.1016/S0140-6736(16)30383-X

Gefen, A., van Nierop, B., Bader, D. L., \& Oomens, C. W. (2008). Strain-time cell-death threshold for skeletal muscle in a tissue-engineered model system for deep tissue injury. Journal of biomechanics, 41(9), $2003-2012$. https://doi.org/10.1016/j.jbiomech.2008.03.039

Gong, X., Liu, Z., \& Wu, T. (2018). Gender differences in the antecedents of trust in mobile social networking services. The Service Industries Journal, 1-27. https://doi.org/10.1080/02642069.2018.1497162

Hansemark, O. C., \& Albinsson, M. (2004). Customer satisfaction and retention: the experiences of individual employees. Managing Service Quality: An International Journal, 14(1), 40-57. https://doi.org/10.1108/09604520410513668

Husain, S. (2017). The determinants of loyalty in online commerce-An exploratory study in India. The Electronic Journal of Information System. https://doi.org/10.1002/j.1681-4835.2017.tb00599.x

Jimenez, N., San-Martin, S., \& Azuela, J. I. (2016). Trust and satisfaction: the keys to client loyalty in mobile commerce. Academia Revista Latinoamericana de Administración, 29(4), 486-510. https://doi.org/10.1108/ARLA12-2014-0213

Komara, E. K. (2015). Manfaat Badan Usaha Milik Desa (BUM Desa) bagi Masyarakat (Telaah Kajian Manfaat Keberadaan BUM Desa 'Hanyukupi'Ponjong dan BUM Desa 'Sejahtera'Bleberan di Kabupaten Gunungkidul). Yayasan Penabulu.

Kotler, P., \& Keller, K. L. (2004). Fundamentals of Marketing Management. Translated by Ali Parsaeian, Termeh Publication.

Kumar, V., Abbas, A. K., \& Aster, J. C. (2017). Robbins basic pathology e-book. Elsevier Health Sciences.

Luarn, P., \& Juo, W. J. (2010). The role of trust in technology within the TAM in the context of NFC mobile payment. Journal of Information and Optimization Sciences, 31(4), 875-896. https://doi.org/10.1080/02522667.2010.10700000

Masrek, M. N., Omar, N., Uzir, N. A., \& Khairuddin, I. E. (2012). Mobile banking utilizations, satisfaction and loyalty: a case study of Malaysian consumers. Science Series Data Report, 4(12), 20-29.

Melaning, A., \& Giantari, I. (2019). Technology acceptance application model on internet banking service in BRI Bank Denpasar Indonesia. International Research Journal of Management, IT and Social Sciences, 6(4), 135-146. https://doi.org/10.21744/irjmis.v6n4.667

Suariedewi, I. G. A. A. M., \& Suprapti, N. W. S. (2020). Effect of mobile service quality to e-trust to develop esatisfaction and e-loyalty mobile banking services. International Research Journal of Management, IT and Social Sciences, 7(1), 185-196. https://doi.org/10.21744/irjmis.v7n1.836 
Mulyawan, A., \& Sidharta, I. (2014). Determinan Kualitas Layanan Akademik Di STMIK Mardira Indonesia Bandung. Jurnal Computech \& Bisnis, 8(1), 13-24.

Permana, H., \& Djatmiko, T. (2018). Analisis pengaruh kualitas layanan elektronik (e-service quality) terhadap kepuasan pelanggan shopee di bandung. Sosiohumanitas, 20(2), 64-78. https://doi.org/10.36555/sosiohumanitas.v20i2.112

Revita, A. (2016). E-Satisfaction Dan E-Trust Mempengaruhi E-Loyalty Konsumen Wanita Dalam Sosial Media. PERFORMA, 1(4), 505-513.

Robbins, P. (2001). Fixed categories in a portable landscape: the causes and consequences of land-cover categorization. Environment and Planning A, 33(1), 161-179. https://doi.org/10.1068\%2Fa3379

Tjiptono, F. (2006). Manajemen Jasa. edisi pertama. yogyakarta: Andi.

Yaqin, A., \& Ilfitriah, A. M. (2015). Pengaruh Kualitas Pelayanan Terhadap Kepuasan Dan Loyalitas Nasabah Bank Pengguna E-Banking Di Surabaya. Journal of Business \& Banking (JBB), 4(2), 245-160. http://dx.doi.org/10.14414/jbb.v4i2.375

Zoghlami, M., Kadri, A., \& Bacha, F. (2018). Analysis and application of the sliding mode control approach in the variable-wind speed conversion system for the utility of grid connection. Energies, 11(4), 720. https://doi.org/10.3390/en11040720 